\title{
Radioterapia przedoperacyjna w raku odbytnicy? Głos na nie
}

\author{
Łukasz Dziki, Adam Dziki
}

\section{Should preoperative radiotherapy be standard procedure for locally advanced rectal cancer? NO}

Na wstępie musimy przyznać, że jest nam bardzo trudno być oponentami niniejszej debacie, gdyż jesteśmy zwolennikami tej metody, ale skoro mamy stanąć po drugiej stronie, to jesteśmy gotowi.

Aby ocenić wartość radioterapii przedoperacyjnej w leczeniu raka odbytnicy, należy zadać sobie następujące pytania, czy radioterapia ma wpływ na:

- przeżycie,

- wznowy miejscowe,

- gojenie zespoleń,

- gojenie rany krocza,

- funkcję zwieraczy,

- występowanie wtórnych raków,

- popromienne zapalenie jelit, pęcherza,

- złąmania kości, powikłąnia "sercowe".

Bardzo znane badanie holenderskie, w którym uczestniczyło 1861 chorych na raka odbytnicy, zostało randomizowanie podzielone na dwie grupy. Pierwsza, z przedoperacyjną radioterapią, i druga - leczona tylko chirurgicznie [1]. Badanie było bardzo wartościowe, gdyż kontrolowano jakość radioterapii, jakość techniki chirurgicznej i jakość badania patologicznego. Badanie wykazało, że wznowy miejscowe były statystycznie znamiennie rzadsze, natomiast nie stwierdzono wpływu radioterapii neoadiuwantowej na przeżycia. 5-letnie przeżycia wynosiły w obu grupach odpowiednio $64,2 \%$ vs $63,5 \%$. Co ciekawe, również analiza przeżyć w tej samej grupie po 12 latach nie wykazała różnic: $47,6 \%$ vs $48,8 \%$.

W pracy Ferenschilda przedstawiono wyniki leczenia 103 chorych na raka w stopniu zaawansowania T2-T3, N0 operowanych w latach 1996-2003 [2]. Średni czas ob- serwacji wynosił 4,3 roku. Wznowa miejscowa wystąpiła u $6 \%$ operowanych chorych, natomiast 5-letnie przeżycia wyniosły $82 \%$. We wnioskach autorzy podają, że radioterapia nie ma wpływu na wznowy i przeżycia u chorych na raka odbytnicy. Wiele prac dowodzi, że to chirurg jest ważnym czynnikiem ryzyka nawrotu raka jelita grubego. Propagator techiki TME, czyli całkowitego wycięcia mesorectum, prof. Bill Heald opublikował swoje wyniki leczenia chirurgicznego, gdzie wznowy miejscowe były stwierdzane tylko u 5\% operowanych chorych.

Ważną kwestią, jak wspominaliśmy, jest wpływ przedoperacyjnej radioterapii na gojenie zespoleń. Vermueller w swej pracy przedstawił dramatyczne wyniki. Nieszczelność zespoleń u chorych poddanych napromienieniu dotyczyła $41 \%$ vs $4 \%$, u tych którzy nie mieli radioterapii [3]. Ponadto Hassan i wsp. wykazali w swych badaniach, że radioterapia przedoperacyjna jest czynnikiem ryzyka stałej stomii u chorych operowanych z powodu raka odbytnicy [4]. Steizmueller i wsp. również wykazali, że radiochemioterapia zwiększa odsetek nieszczelności oraz zaburza gojenie rany krocza. Właśnie doatkowo gojenie rany na kroczu po brzusznokroczowym wycięciu odbytnicy jest ważnym problemem klinicznym [5]. Salmenkyla i wsp. stwierdzili znamiennie częstsze występowania zakażeń pooperacyjnych: 26,2\% vs $15,5 \%$ oraz rozejść rany na kroczu: $38,5 \%$ vs $15,9 \%$ [6]. Podobne wyniki opublikował Hoare i wsp. [7]. Według Aldulaymiego czas gojenia rany kroczowej wyniósł 122 dni w stosunku do 22 dni u chorych, którzy nie mieli radioterapii.

W wielu pracach udowodniono, że radioterapia przedoperacyjna powoduje gorsze wyniki czynnościowe u chorych operowanych z powodu raka odbytnicy [8]. Parc i wsp.

Klinika Chirurgii Ogólnej i Kolorektalnej

I Katedra Chirurgii

Uniwersytet Medyczny w Łodzi

Wystąpienie podczas I Konferencji Naukowej czasopisma Nowotwory „Debaty onkologiczne” 5-6 kwietnia 2013 roku 
w swojej pracy podali, że chorzy napromieniani częściej mieli wypróżnienia, częściej uczucie konieczności nagłego oddania stolca, jak również problemy natury seksualnej [9]. Badania oparte na grupie holenderskiej wykazały znamienną różnicę nietrzymania stolca wśród chorych, którzy przebyli radioterapię, w stosunku do chorych tylko operowanych, a nie napromienianych. Różnice dotyczyły również w nietrzymaniu stolca w nocy i odsetka chorych, u których wystąpiło brudzenie bielizny i konieczność noszenia podpasek. Ciekawa praca ze Szwecji przedstawiła odległe powikłania u chorych operowanych z powodu raka odbytnicy po przedoperacyjnej radioterapii $5 \times 5$ Gy. W tej grupie stwierdzono więcej powikłań układu krążenia, częściej też występowało nietrzymanie stolca i nietrzymanie moczu [10]. Wytłumaczeniem tego zjawiska jest prawdopodobnie występujące włóknienie mięśni zwieraczy po radioterapii, jak również bliznowacenie pozostawionego odcinka odbytnicy, który jest pozbawiony możliwości rozciągania i adaptacji bańki odbytniczej.

Niezmiernie ważnym problemem u chorych napromienianych jest ryzyko wystąpienia wtórnych nowotworów. Spostrzeżenie to potwierdza wiele prac [11-15].

Następnym powikłaniem występującym znamiennie częściej u chorych poddanych radioterapii przedoperacyjnej jest ryzyko złamania kości miednicy oraz kości kończyn.

Bardzo ważną kwestią, dotyczącą przede wszystkim młodych chorych, są powikłania seksualne po operacji raka odbytnicy, poprzedzonej napromienieniem. W znacznym odsetku występują u tych chorych: impotencja, zaburzenia ejakulacji, bolesne stosunki, zmniejszenie nawilżenia pochwy.

Czy istnieją zatem wskazania do radioterapii przedoperacyjnej u chorych na raka odbytnicy? Oczywiście, że tak. Trzeba jednak pamiętać, że kluczem do osiągnięcia najlepszych wyników leczenia jest określenie stopnia zaawansowania raka. Dopiero po badaniach diagnostycznych należy zaplanować właściwe leczenie. Każdy chory przed leczeniem powinien mieć ustalone leczenie po wspólnej konsultacji chirurga, onkologa i radioterapeuty. Trzeba pamiętać, że operacja w ośrodku dysponującym świetnie wyszkoloną i doświadczoną kadrą daje największe szanse uzyskania bardzo dobrych wyników leczenia. Sposób leczenia chorego na raka odbytnicy musi być dobrany indywidualnie do stanu jego zdrowia I stopnia zaawansowania raka.

Prof. dr hab. n. med. Adam Dziki

Klinika Chirurgii Ogólnej i Kolorektalnej

I Katedra Chirurgii UM

Uniwersytecki Szpital Kliniczny

Plac Hallera 1, 90-647 Łódź

e-mail:adziki@wp.pl

\section{Piśmiennictwo}

1. Peeters KC i wsp. The TME trial after a median follow-up of 6 years: increased local control but no survival benefit in irradiated patients with resectable rectal carcinoma. Ann Surg 2007; 246: 693-701.

2. Ferenschild FT i wsp. Preoperative radiotherapy has no value for patients with T2-3, N0 adenocarcinomas of the rectum. Dig Surg 2009; 26: 291-296.

3. Vermueller J i wsp. Impaired anastomotic healing after preoperative radiotherapy followed by anterior resection for treatment of rectal carcinoma. S Afr J Surg 2006; 44: 14-16.

4. Hassan I i wsp. Impact of pelvic radiotherapy on morbidity and durability of sphincter preservation after coloanal anastomosis for rectal cancers. Dis Colon Rectum 2008; 51: 32-37.

5. Steizmueller J i wsp. Postoperative morbidity following chemoradiation for locally advanced low rectal cancer. Gastrointest Surg 2009; 13: 657-667.

6. Salmenkyla Si wsp. Does preoperative radiotherapy with postoperative chemotherapy increase acute side-effects and postoperative complications of total mesorectal excision? Report of the randomized finnish rectal cancer trial. Scand J Surg 2012; 101: 275-282.

7. Hoare D i wsp. Does pre-operative chemoradiotherapy cause wound complications after abdominoperineal excision for rectal cancer? An observational study. Int J Surg 2013; 11: 395-399.

8. Aldulaymi BH i wsp. Perineal wound complications following preoperative radiotherapy for rectal cancer. Ugeskr Laeger 2008; 170: 1225-1227.

9. Parc Y i wsp. Preoperative radiotherapy is associated with worse functional results after coloanal anastomosis for rectal cancer. Dis Colon Rectum 2009; 52: 2004-2014.

10. Lange MM. Risk factors for faecal incontinence after rectal cancer treatment. Br J Surg 2007; 94: 1278-1284.

11. Peeters KC i wsp. Late side effects of short-course preoperative radiotherapy combined with total mesorectal excision for rectal cancer: increased bowel dysfunction in irradiated patients - a Dutch colorectal cancer group study. J Clin Oncol 2005; 23: 6199-6206.

12. Pollack J i wsp. Late adverse effects of short-course preoperative radiotherapy in rectal cancer. Br J Surg 2006; 93: 1519-1525.

13. Birgisson i wsp. Occurrence of second cancers in patients treated with radiotherapy for rectal cancer. J Clin Oncol 2005; 23: 6126-6131.

14. Marijnen CA i wsp. Impact of short-term preoperative radiotherapy on health-related quality of life and sexual functioning in primary rectal cancer: report of a multicenter randomized trial. J Clin Oncol 2005; 23: 1847-1858.

15. Den Dulk M i wsp. Improved overall survival for patients with rectal cancer since 1990: the effects of TME surgery and pre-operative radiotherapy. Eur J Cancer 2008; 44: 1710-1716. 